\section{Intersections}

Canadian Journal of Music

Revue canadienne de musique
Intersections CANADIAN JOURAL OF MUSIC
REVUE CANADIENEE DE MUSIOUH

\title{
Decolonizing Desires and Unsettling Musicology: A Settler's Personal Story of Researching and Teaching Indigenous Music at an American University
}

\section{Alexa Woloshyn}

Volume 39, numéro 1, 2019

Decolonizing Music Pedagogies

URI : https://id.erudit.org/iderudit/1075341ar

DOI : https://doi.org/10.7202/1075341ar

Aller au sommaire du numéro

Éditeur(s)

Canadian University Music Society / Société de musique des universités canadiennes

ISSN

1918-512X (numérique)

Découvrir la revue

Citer cet article

Woloshyn, A. (2019). Decolonizing Desires and Unsettling Musicology: A Settler's Personal Story of Researching and Teaching Indigenous Music at an American University. Intersections, 39(1), 41-55.

https://doi.org/10.7202/1075341ar
Résumé de l'article

Pour ceux d'entre nous qui ont des désirs décoloniaux, la salle de classe universitaire est un espace potentiel de rupture et de réorganisation. Nos cours, notre matière, nos outils pédagogiques, nos étudiant-e-s et nos propres corps et esprits sont autant de technologies qui peuvent renverser la machine coloniale (la paperson 2017). Dans la première section, je contextualise mes désirs décoloniaux en tant que musicologue canadienne, non-citoyenne américaine aux États-Unis. Les travaux de David Garneau,

Aileen Moreton-Robinson, Andrea Smith, Eve Tuck et K. Wayne Yang soulignent mon positionnement et mon pouvoir. Dans la deuxième section, je donne en exemple une façon dont je perturbe les programmes et les expériences universitaires typiques dans une école de musique classique euroaméricaine. Je discute de mon cours intitulé « North American Indigenous Music Seminar " (NAIMS), notamment la structure et le contenu du cours, ainsi que les stratégies de décolonisation. Les réponses des étudiant-e-s aux entretiens sur le cours sont entrecoupées de la discussion de mes plans de séminaire et des défis relatifs à la " décolonisation ». Leurs réponses révèlent quelques succès et de nombreuses limites au travail anticolonial et décolonial dans un cours d'un semestre. (c) Canadian University Music Society / Société de musique des universités canadiennes, 2021
Ce document est protégé par la loi sur le droit d'auteur. L’utilisation des services d'Érudit (y compris la reproduction) est assujettie à sa politique d'utilisation que vous pouvez consulter en ligne.

https://apropos.erudit.org/fr/usagers/politique-dutilisation/ 


\title{
DECOLONIZING DESIRES AND UNSETTLING MUSICOLOGY: A SETTLER'S PERSONAL STORY OF RESEARCHING AND TEACHING INDIGENOUS MUSIC AT AN AMERICAN UNIVERSITY
}

\author{
Alexa Woloshyn
}

Where do you begin telling someone their world is not the only one?

-Lee Maracle (Sto:lo)

I am a white, cis-woman settler. Growing up on the Canadian prairies, I experienced white privilege within a Canadian settler colonial nation-state upheld by a racialized system of power. For the longest time, I did not recognize that my world was built from a hetero-patriarchal, white supremacist, settler-colonial world view. I was willingly unaware that I lived on Métis and Cree lands. Treaty 6 (1876) was an agreement on shared rights, responsibilities, and usage of land between the Indigenous and settler state signatories. ${ }^{1}$ Treaty 6 is still in effect, despite the settler state not upholding it for nearly 145 years. I have lived, been educated, and worked on stolen Indigenous land. I continue to live, work, and now own property on stolen Indigenous land, in what is currently Pittsburgh, Pennsylvania. Eve Tuck and K. Wayne Yang warn that such realizations as these-such critical statements of settler colonialism-can convince me that I am making real change $(2012,21)$. Yet I remain a settler who benefits from settler colonialism. How, then, can I become an unsettled settler? An unsettled researcher and educator?

This is a mixed-form article: it begins with a reflection in which I consider my work as a settler Canadian musicologist who supports decolonial efforts of Indigenous Peoples in North America but is still benefitting from class and racial privileges that uphold the Canadian and U.S. settler states. David Garneau, Aileen Moreton-Robinson, Andrea Smith, Eve Tuck, and K. Wayne Yang illuminate my current situation as a non-citizen professor in the United States. In the second section, I discuss my university course entitled "North American

1 Treaty 6 territory covers the central portions of Alberta and Saskatchewan. The Crown signed a treaty with representatives of the Cree (Plains and Wood), Saulteaux, Assiniboine (Nakota), and Chipewyan (Dene). 
Indigenous Music Seminar" (NAIMS), including the course structure, content, and decolonizing strategies. Excerpts from student interviews are interspersed as I explain my pedagogical intentions and problematize claims of "decolonizing pedagogies." The student responses reveal some successes and many limits for anti-colonial and decolonial goals in a single-semester course. My university and the structures therein contain technologies that serve the colonial project but could be repurposed for decolonial desires (la paperson 2017). I seek to identify the technologies operating in my sphere and disrupt and reorganize them.

\section{What, Why, and How Does a Settler Non-Citizen Musico- LOGIST DECOLONIZE?}

Paulette Regan argues that decolonization "involves a paradigm shift from a culture of denial to the making of space for Indigenous political philosophies and knowledge systems as they resurge, thereby shifting cultural perceptions and power relations in real ways" (2010, 189; my emphasis). Tuck and Yang are even more direct: "Decolonization specifically requires the repatriation of Indigenous land and life" $(2012,21)$. What can I do as a researcher and an educator that is more than rhetoric (i.e., metaphor)?

"Within the colonizing university also exists a decolonizing education," la paperson declares (2017, xiii). ${ }^{2}$ The decolonizing university is not itself decolonized, but rather it "equips its students with skills toward the applied practice of decolonization" (36). La paperson offers few specifics about this "applied practice," which thus leads me to more questions about my research and teaching practices. I believe I can participate in anti-colonial and decolonial projects by assembling "decolonizing machines out of scrap parts of colonial technology" (53). My current assemblage targets my agency within the music curriculum: What technologies do I see in operation? How do they operate? How can I disrupt and reorganize them?

However, such decolonial desires are complicated by my position as a university musicology professor. Much of my current research as a musicologist is about contemporary Indigenous musicians such as Tanya Tagaq (2012; 2017), A Tribe Called Red (2015, 2016, 2019), and Cris Derksen (2020) as Indigenous artists working within and across Euro-American popular and classical genres. I am indebted to artist, activist, and scholar David Garneau in helping me understand how settler colonialism is pervasive in academia. Garneau explains: "The colonial attitude, including its academic branch, is characterized by a drive to see, to traverse, to know, to translate (to make equivalent), to own, and to exploit. It is based on the belief that everything should be accessible, is ultimately comprehensible, and a potential commodity or resource, or at least something that can be recorded or otherwise saved" $(2012,32)$. Garneau's words strike hard. What I had convinced myself was a commendable pursuit is only an extension of the insatiable colonial hunger to own and exploit. While Garneau's

\footnotetext{
2 "La paperson" is the occasional pen name of K. Wayne Yang.
} 
criticisms can be charged against academia more broadly, I see three problems with musicology in particular: first, the ex-nomination of white supremacy and Euro-centrism through the unmarked "music" in institutional, program, and course titles (e.g., "School of Music") (Kajikawa 2019: Attas 2019); second, legacies of freely using musical texts without non-Western consideration of appropriation, protocol, and ownership (Strachan and Nickleson 2018); and third, institutional "othering" of non-Euro-American classical music through the disciplinary separation of musicology and ethnomusicology (Amico 2020).

I used to think that I was entitled to any knowledge or sources that would answer my research question. I have since developed a research ethic that respects an individual's and a group's right not to disclose. Some knowledge is inaccessible to me because I do not belong to the community from which the knowledge comes, I have not been taught the proper protocols for using that knowledge, or I exist outside a community's mechanisms for accountability, among other reasons. "Nothing about us without us" is a phrase repeated by Indigenous communities and artists rejecting exploitation. ${ }^{3}$

My seminar is the outcome of my ongoing research. My students are also required to complete research for their large projects. Thus, I model a research ethic to my students. I am transparent with my students about my questions and process. Here, again, Garneau is an essential guide. I ask, What is the relationship model for a settler's research of Indigenous musicians? Garneau rejects the term "reconciliation" because it suggests that quest is "repair to a previously harmonious relationship" $(2016,30)$. "Conciliation" underlines the need to establish a harmonious relationship between sovereign parties. What does a conciliation model of research and collaboration look like? My internalized default is to apply settler colonial logic to uphold the hegemony of whiteness and reinforce Indigenous Peoples as a homogenous "Other" in my classroom. Aileen Moreton-Robinson (2015) calls whiteness "the norm" in U.S. academic institutions, so I am working against disciplinary norms that have been internalized.

Settler colonialism in the United States, as elsewhere, was instituted and is upheld by white supremacy (Smith 2012; Bonds and Inwood 2016; Moreton-Robinson 2015). Power positions within settler colonialism are important to understand in the classroom, with students of various ethnic and racial backgrounds. "Settler" is not an identity but rather a relationality with resulting power dynamics within the "settler-native-slave triad" (Tuck and Yang

3 A quick note on terminology: "Aboriginal" is an official term used by the Canadian government to refer to First Nations, Métis, and Inuit. It was also a common term used by Indigenous writers. In many instances, "Indigenous" has replaced "Aboriginal," a shift led by Indigenous Peoples. I use "Indigenous" when speaking generally and use specific nation/tribal terms when applicable. When discussing official documents/policies or paraphrasing someone else's writing, I use the terminology found therein. Vowel (2016) and Younging (2018) address terminology, though both are focused on the Canadian context. The term "Native American" is common in the United States, with many Indigenous individuals choosing to call themselves "Native" in addition to specific tribal/nation identification. 
2012, 17; see also Vowel 2016, 16; la paperson 2017, 6-12).4 Most of my students are white. Thus, the idea of calling themselves "settlers" is a significant shift. In both the first and second iterations of this seminar, I had a small number of students of colour. Given my power position as their white, cis, heterosexual professor, I needed to be sensitive to how my students do or do not have access to power and privilege within the university and broader society.

As a university musicology professor in the United States, I am holding myself accountable for my privilege, undoing habits of research and teaching based in settler colonial white supremacy, and developing new modes of thinking and doing. A community of scholars-settler, Indigenous, and Black-has helped me transform my citational practice, research ethics, and understanding of settler colonialism as an ongoing structure. This help has come in the form of conference presentation feedback, reviewer comments, published scholarship, Twitter threads, informal conversations, and even direct messages. Because of the online components of this community, my move from Canada to the United States has not been entirely disruptive. However, similar discussions have minimal presence on campus and in the city where I have now resettled. This apparent absence has forced me to search harder for like-minded individuals, and a new community of scholars is forming that gathers in shared spaces in Pittsburgh.

The erasure of Indigenous presence in the Pittsburgh region is shocking. "There are no Indians in Pennsylvania" is the first line in David J. Minderhout and Andrea T. Frantz's book Invisible Indians $(2008,1)$ and a phrase they repeatedly heard during their fieldwork. Despite this belief's stronghold in public opinion, Indigenous Peoples have existed on these lands for millennia. Unfortunately, as with many regions of the United States, the belief is that Native Americans all left and are on reservations, are dead, or are not "real" Indians (King 2012; Peters and Andersen 2013; Tuck and Yang 2012). There are no Native Studies departments in any of the local universities, a negligible number of courses on Native American topics, and few Native American faculty in Pittsburgh. Pennsylvania has no federally or state-recognized Indigenous nations, so the invisibility is official within the settler state. Because of this official erasure, I have sought out local Indigenous organizations and individuals. The main organization is the Council of Three Rivers American Indian Center (COTRAIC), which hosts the annual powwow and is the hub for the Indigenous community in this region. 5 The East Coast Two Spirit Society (EC2SS) is also based here, and this is another community with whom I am building a relationship.

4 Both Vowel and Tuck and Yang explain that "settler" can never apply to the descendants of Africans enslaved in the Americas. Vowel prefers to use the term "non-Black people of colour" (2016, 17) to refer to non-European-descended peoples who come to Canada, which we could also apply to the United States. Such a term allows us to differentiate between those who have more privilege within Canada or the United States through white privilege and those who remain subject to racial discrimination.

5 In the second iteration of this seminar, my students hosted a film night for Native American Heritage Month with members of COTRAIC as respondents. 
As a non-U.S.-citizen, I have significantly less power to wield within the settler state; I can easily be removed. Yet, while I live in a settler colonial society founded on white supremacy and hetero-patriarchy, I still have power. I aim to make resources accessible to me as a white cis-woman university professor available for these organizations and communities to achieve their goals. A recent community event hosted by my institution was the first time that COTRAIC had been invited to campus. Many of my colleagues and I hope that this initiates a long-standing relationship based on respect, reciprocity, and conciliation. Garneau articulates our hopes: "A purpose of anti-racist work is for settlers to learn more about their hosts and hosts to know more about their guests, to move through proximity, listening, empathy, cooperative inquiry, and action" $(2016,29)$.

My question persists, though: How can I become an unsettled settler? Garneau writes, "Settlers who become unsettled-who are aware of their inheritance and implication in the colonial matrix, who comprehend their unearned privileges and seek ways past racism-are settlers no longer ... [T] hey have become respectful guests, which in turn allows Indigenous peoples to be graceful hosts" $(2012,32)$. For the academic context, la paperson provides some additional clues. He declares that the "assemblage of machines" of an academic institution "is always being subverted toward decolonizing purposes" (2017, xiii). Though as a male settler of colour scholar, Yang (writing as la paperson) is treated differently from me within the structure of settler colonialism, his confessions mirror my thoughts: "My position is impossible, a colonialist-by-product of empire, with decolonizing desires. I am, and maybe you are too, a produced colonialist" (xxiii). La paperson implores those of us committed to decolonial work, "Figure out how technologies operate. Use a wrench. Technology can be disrupted and reorganized" $(2017,24)$.

This call to action is my current puzzle: What technologies do I see in operation? How do they operate? How can I disrupt and reorganize them? My "North American Indigenous Music Seminar" is one small way that I am implementing this call to action by disrupting the typical curricula and classroom experiences in Euro-American classical music schools.

\section{North AmErican Indigenous Music SEMinar: Implementa- TION, FEedback, AND STRUCTURE}

In the Spring 2018 semester, I first offered the graduate ${ }^{6}$ seminar "North American Indigenous Music," and I plan to offer it every other year. Indigenous teachers would be best for this course (Keene 2019; Appleton 2019) because they have an expertise that I can never acquire as a non-Indigenous scholar. Cherokee scholar Adrienne Keene wrote an op-ed (2019) discussing how non-Indigenous faculty can teach Indigenous topics (in this case, a hypothetical Native literature course). Keene explains that virtual and in-person guests are a relatively easy way to centre Indigenous voices in the classroom.

6 Undergraduate students may enrol with permission and space available. 
Chickasaw composer Jerod Impichchaachaaha' Tate joined our class for a video chat. For students, Tate's virtual visit was a compelling class experience: they learned from an Indigenous individual although their professor was non-Indigenous, and, furthermore, from an Indigenous musician working within a Euro-American classical genre. The students expressed a strong desire to host Tate at our university, and I coordinated a short residency with Tate in the following semester to work with our Contemporary Music Ensemble. Several former seminar students were thrilled to play his music and learn from him in person. I am collaborating with local Indigenous musicians and speakers to be more involved in subsequent course offerings and campus activities. ${ }^{7}$

To non-Indigenous professors, in particular, Keene (2019) encourages consenting to learn in public. This means being transparent with students about my knowledge limitations as a non-Indigenous professor and making my position as a white non-Indigenous settler clear from day one. I share my concerns as a researcher writing about Indigenous musicians with my students and explain how avoiding exploitative behaviours requires different research and relational ethics.

According to institution demographic data from 2018, no School of Music students were Native American. ${ }^{8}$ On the basis of these data and my experience at the university thus far, I anticipated that my class would be mostly white students, one to two non-United States citizens, and a relatively even ratio of female and male students. ${ }^{9}$ Course enrolment aligned with these overall demographics of the School of Music. The twelve students in the seminar's first iteration had various motivations for enrolment. For instance, Tara ${ }^{10}$ had previously taken a course with me in which we had covered some musical practices of Indigenous Peoples in North America, and she wanted to learn more. Jackie enrolled at Tara's recommendation. In class discussions, assignments, and research interviews conducted after the course was finished, students admitted their knowledge gaps and expressed desires to learn about Indigenous Peoples.

Keene (2019) emphasizes curating the syllabus reading list, a task on which I also had focused. In a music course, musical works are core "texts" to be read (Attas 2019). Such listening examples were always considered in relation to Indigenous-authored readings, both academic and non-academic. Keene's standard for each selection is whether it is "working toward a goal of decentering settler colonialism and centering Indigenous peoples" (2019). I paired musical genres and musicians with relevant historical, socio-cultural contexts. For example, we studied several different artistic projects by Inuk artist Tanya Tagaq

7 In the second iteration, we hosted two events for Native American Heritage Month (NAHM), including an artist workshop with Black Meherrin artist Morgan Overton. While such awareness months can be tokenistic, in a city and on a campus with no official recognition of NAHM or events of any kind, my seminar's gatherings can be positively disruptive.

8 Detailed data for the School of Music are available only to affiliates of my university.

9 The university gathers only binary gender information.

10 I invited all students who had successfully completed the seminar to participate in an IRB-approved study. Each of the five students who completed the interview (three women; two men) has been assigned a pseudonym. 
through the lens of Inuit sovereignty and self-determination: we listened to her album Animism (2014), discussed how she used this album and its publicity to foster awareness of the Inuit seal hunt, and watched Alethea Arnaquq-Baril's Angry Inuk. ${ }^{11}$ We studied A Tribe Called Red's music and videos (many of which confront Hollywood's Native American stereotypes), learned about the impact of Native mascots, and discussed cultural appropriation. One student, Jackie, explained that our class's tackling of cultural appropriation affected her daily life: "I'm definitely more aware of cultural appropriation. I come across it every day." We also listened to musical depictions of and responses to the residential school system, ${ }^{12}$ and considered Indigenous critiques of projects led by (or entirely populated by) non-Indigenous artists, such as the ballet Going Home Star (2014) and the album Secret Path, alongside the animated film adaptation of Jeff Lemire's graphic novel.

Keene also suggests focusing on contemporary Indigenous writers in order to "explode their [students'] stereotypes." The seminar challenged several stereotypes but especially the stereotype that urban-based Indigenous Peoples are inauthentic. While my seminar included musical practices that have long historical legacies, we studied mostly living musicians who work within both so-called traditional genres (a concept we interrogated; see Browner 2009; Hoefnagals and Diamond 2012; Levine and Robinson 2019) and more contemporary popular idioms. We read selections from Peters and Andersen's Indigenous in the City (2013), listened to Indigenous hip hop (e.g., Tall Paul), and discussed A Tribe Called Red's Electric Pow Wow night in Ottawa and urban powwows. Sam, a student from the Dominican Republic, found that these contemporary contexts were central to his interests: "I wanted to know what Native Americans went through, what the music was, where they are at culturally right now. What it means to be Native American at this point. And I feel like I got a lot of those answers through the course."

Because of my students' intimate knowledge of the Euro-American classical canon, we completed a section on what Mohawk composer and scholar Dawn Avery calls "Native American classical music" (2012). We discussed Indigenous composers writing for Euro-American classical genres, such as Jerod Tate, Cris Derksen, Dawn Avery, and Tagaq's work with the Kronos Quartet. More than one student declared they were eager to learn about music outside of the canon

11 Tagaq's music is used in the film. In addition, the \#sealfie movement, in which Tagaq participated (Woloshyn 2017), is discussed in the film.

12 Both Canada and the United States had church- and government-sponsored boarding/residential schools for Indigenous children and youth. These institutions were initially designed to "civilize" Indigenous students and assimilate them into the dominant settler (specifically, white) culture through the suppression of language and culture, resulting in cultural genocide (TRC 2015; Stout 2012). Schools in Canada were open from 1867 (and some even prior to Confederation) to 1998. Compulsory attendance was instituted in the Indian Act in 1884. In the United States, schools were open from the early nineteenth century (the official government-sponsored era began in 1879) to today. In the United States, Richard Pratt's "Kill the Indian, Save the Man" motto and his Carlisle Indian Industrial School were the models across the country. Attendance was made compulsory in 1891 until 1978, with the passing of the Indian Child Welfare Act. In the last few decades, U.S. schools that are still open have rejected their openly assimilationist agendas, such as Haskell Indian Nations University (formerly United States Indian Industrial Training School). 
typically reinforced in classes, ensembles, and private lessons at my institution and elsewhere. Matt explained, "By the time you're working on your master's of music, you don't learn a lot of new things. You can only re-state and recycle some of the same material about Beethoven, and Brahms, and Schoenberg so many times. So a lot of this was very fresh, and I appreciated that." Jackie exclaimed, "Indigenous music is still happening. There are live composers composing. Beethoven is long gone." The seminar also devalued the hierarchies implicit within the canon that reinforce high/low, classical/popular (or classical/traditional) binaries, such as in Cris Derksen's Orchestral Powwow. Matt explained, "There was a lot of classes when I came or did a reading, and I was just surprised by the art forms that I was hearing and seeing. Something [sic] that are atypical or aren't as 'high.' ... We ignored those categories.... That was welcome and refreshing."

The seminar explored the heterogenous collection of musical genres and musicians through four themes outlined in table 1.

Table 1: Structural Outline and Content Summary for NAIMS

\begin{tabular}{|c|c|c|c|}
\hline Theme & Topics & Musicians/genres & Authors/filmmakers \\
\hline Cultural genocide & $\begin{array}{l}\text { History of settler } \\
\text { colonialism in North } \\
\text { America;a residen- } \\
\text { tial school system } \\
\text { (Canada) and Indian } \\
\text { boarding schools } \\
\text { (United States); pow- } \\
\text { wow and round dance } \\
\text { as resurgence }\end{array}$ & $\begin{array}{l}\text { Critique of non-In- } \\
\text { digenous depictions } \\
\text { of the residential } \\
\text { school system (IRS);b } \\
\text { Indigenous artists on } \\
\text { IRS, including Leela } \\
\text { Gilday, Mishi Donovan, } \\
\text { and Susan Aglukark; } \\
\text { powwow, with groups } \\
\text { Black Bear, Black } \\
\text { Lodge Singers, North- } \\
\text { ern Voice, Northern } \\
\text { Cree, and Chippewa } \\
\text { Travellers }\end{array}$ & $\begin{array}{l}\text { Louis Ballard; Erica } \\
\text { Commanda; Truth } \\
\text { and Reconciliation } \\
\text { Commission: "What } \\
\text { We Have Learned" }\end{array}$ \\
\hline Nation to nation & $\begin{array}{l}\text { Idle No More; } \\
\text { Indigenous-settler } \\
\text { collaborations }\end{array}$ & $\begin{array}{l}\text { Intertribal flute music; } \\
\text { Idle No More flash } \\
\text { round dances; Electric } \\
\text { Powwow; opera, string } \\
\text { quartet, orchestral } \\
\text { works; Louis Riel } \\
\text { opera revival }\end{array}$ & $\begin{array}{l}\text { Adam Gaudry, Idle No } \\
\text { More founders, Ryan } \\
\text { McMahon, John-Car- } \\
\text { los Perea, Truth } \\
\text { and Reconciliation } \\
\text { Commission: "Calls to } \\
\text { Action" }\end{array}$ \\
\hline $\begin{array}{l}\text { Sovereignty and } \\
\text { self-determination }\end{array}$ & $\begin{array}{l}\text { Representation of } \\
\text { Indigenous Peoples } \\
\text { in mainstream culture; } \\
\text { Indigenous musicians } \\
\text { within Euro-American } \\
\text { genres; Inuit cultural } \\
\text { practices, including } \\
\text { seal hunt }\end{array}$ & $\begin{array}{l}\text { “Classical Native Music” } \\
\text { (phrase from Avery } \\
\text { 2012), including Cris } \\
\text { Derksen, Tanya Tagaq, } \\
\text { and Jerod Impich- } \\
\text { chaachaaha' Tate; Inuit } \\
\text { drum-dance songs } \\
\text { and vocal games (with } \\
\text { the Kettler Sisters, } \\
\text { Tanya Tagaq, Quantum } \\
\text { Tangle, The Jerry } \\
\text { Cans) }\end{array}$ & $\begin{array}{l}\text { Alethea Arnaquq-Baril, } \\
\text { Dawn Avery, Neil } \\
\text { Diamond }\end{array}$ \\
\hline
\end{tabular}




\begin{tabular}{|c|c|c|c|}
\hline Theme & Topics & Musicians/genres & Authors/filmmakers \\
\hline $\begin{array}{l}\text { Identity and decoloniz- } \\
\text { ation: Indigenous now }\end{array}$ & $\begin{array}{l}\text { Language reclamation, } \\
\text { urban-based indigen- } \\
\text { eity, Murdered and } \\
\text { Missing Indigenous } \\
\text { Women and Girls, } \\
\text { decolonial solidarity }\end{array}$ & $\begin{array}{l}\text { Jeremy Dutcher, In- } \\
\text { digenous hip hop, Buffy } \\
\text { Saint-Marie, Eekwol, } \\
\text { Kinnie Starr, A Tribe } \\
\text { Called Red }\end{array}$ & $\begin{array}{l}\text { Chris Andersen, Devon } \\
\text { Abbott Mihesuah, Nan- } \\
\text { cy Marie Mithlo, Janell } \\
\text { Navarro, Karyn Recol- } \\
\text { let, Leanne Betasam- } \\
\text { osake Simpson, John } \\
\text { Trudell, Eve Tuck }\end{array}$ \\
\hline
\end{tabular}

a The second iteration of this seminar overlapped with a symposium on settler colonialism in the United States. Students were required to attend (or watch the recordings after the event). This event emphasized to students that settler colonialism is an ongoing structure.

b While we learned about the laws, stories, and legacies of residential and boarding schools in the United States and Canada, the musical examples were from Canada because of the surge in artistic engagement on the topic during and after the Truth and Reconciliation Commission of Canada.

Each theme concluded with students writing a response and with a class discussion. In each response, students answered several questions:

1. What new knowledge or understanding did I gain during this unit?

2. What did I find surprising and/or confusing during this unit?

3. What musical examples stand out from this unit and for what reasons?

4. What assumptions or beliefs did I have coming into this unit? How have they been reinforced or challenged?

In these responses, students worked hard to confront their assumptions and prior knowledge in the face of new knowledge and Indigenous-centred perspectives. These were graded responses that assessed the synthesis of course materials with individual experiences and knowledge. Students were expected to model the terminology used in the class and readings, and I guided them to reject language that homogenizes, essentializes, and primitivizes Indigenous Peoples. Various levels of familiarity with terminology were permitted to avoid penalizing students who were more novice in understanding language use. However, students were expected to implement changes in language usage that were flagged in previous assignments.

The largest assignment in the course was a creative project on an Indigenous musician/group or musical practice not discussed in class. Music history pedagogues and others demonstrate that encouraging students to find an outlet that better suits their interests and goals results in better quality and more stimulating work than research papers alone (while papers can still exist as a choice for students) (Knyt 2013; Meyer et al. 2014; Adams et al. 2017). In this first iteration, projects included videos about specific musicians, a podcast on Indigenous hip hop artists, a lecture-recital on Métis fiddling, a cooking video on Haudenosaunee foods, and an interactive map-based website on Indigenous musical practices from what is currently Mexico. Students are assessed on their capabilities in selecting and reading Indigenous-centred sources, using appropriate terminology, providing nation- or community-specific context for 
each musician or genre, as well as appropriately matching the medium to the topic and demonstrating sufficient technical skills (as applicable). ${ }^{13}$

This seminar lasts only one semester. I conducted my research interviews with students after the course was completed. I needed to know what, if any, impact this seminar had on students' lives since completing the course. Their interview responses reflect that there was meaningful work during the semester to challenge stereotypes, build new and deeper knowledge, and centre Indigenous voices. However, their responses also demonstrate that decolonial work and decolonizing pedagogies are complicated and messy. Just as I can become entrapped in upholding settler colonialism through reassuring critical self-awareness and falling into any number of settler moves to innocence (see Tuck and Yang 2012, 9-28), so too can my students.

In my students' interview comments, I noticed hints of at least three settler moves to innocence: colonial equivocation; free your mind and the rest will follow; and adoption fantasy (Tuck and Yang 2012). I therefore wondered, What are the signs that my students are ensnared in these moves to innocence? How can I avoid them instead of enabling them (in both myself and my students)?

The settler move to innocence of colonial equivocation (Tuck and Yang 2012, 17-19) was difficult to avoid during the seminar itself, a difficulty also reflected in the student interviews. When students learned about suicide rates, poverty, and racism, for example, experienced by Indigenous Peoples, their first frame of reference was often the oppression of other minoritized and racialized groups. It appeared easy for students to position Indigenous Peoples' stories as merely another kind of oppression in the United States. Social justice efforts fight for rights within settler colonialism and thereby reinforce its power structure, even as the specific groups within it may shift in their access to power and privilege (Smith 2012, 70).

A seminar with so much new knowledge also can lead students dangerously close to what Tuck and Yang phrase as "Free your mind and the rest will follow" $(2012,19)$. Tuck and Yang are critical of how "critical consciousness does not translate into action that disrupts settler colonialism" (19). Student interview comments reflect increased critical consciousness. For example, Tara stated, "I learned some things in recent history with Indigenous people that I didn't know, so that was something that was really, really important to me.... I now have seen news stories about the murdered and missing Indigenous women and have the background now to relate that." Some of my students are educators themselves and want to be ambassadors of Indigenous musics to their classrooms, principally to diversify the Euro-American classical canon. These efforts do not challenge the hegemony of Euro-American classical music. Will they be perpetuating a "free your mind" as a means to relieve "the settler feeling of guilt or responsibility" (21)? Part of my work as an educator and an example of a researcher is emphasizing tangible supports for Indigenous

13 Younging's Elements of Indigenous Style was not available during this first iteration. For their unit responses, in-class presentations, and project bibliographies, this Indigenous style guide would be immensely helpful in reinforcing good habits about terminology, research ethics, and differentiating Euro-American and Indigenous epistemologies. 
communities, especially on the local and regional levels, and being clear about the limits I see in intellectual work.

The changes in their everyday and musical lives that these students articulated are significant. They are unlike any experiences that they have within the School of Music, or even, for many, in any of their post-secondary education. Eva explained one shift to me: "It's little things in everyday life. Being more aware. If you're talking about an Indigenous group, which one? I had this general knowledge, but it made me want to go deeper and question certain things I knew or thought I knew.... It awoke this curiosity." The students intend to bring this seminar experience into future endeavours. Sam discussed his goals about law school and beyond: "One of the programs I'm applying to has Native American law.... I don't know exactly where my path is going to lead getting into law school, but having gone through the class, I see a bigger realm of opportunities." Sam could end up forging powerful decolonizing partnerships with Indigenous communities. However, he could also fall into a kind of settler adoption fantasy (another move to innocence), by which he feels like the rightful custodian, superior to both settler and Native, a cultural hybrid (Tuck and Yang 2012, 13-17). I cannot know what Sam will do, but I hope he is truly an ally and guest.

\section{"Make It Pump for Your Decolonizing Enterprise"}

Upon reflection on my seminar and my so-called decolonial pedagogies, I conclude that they would be more accurately labelled with different terms. In early 2019, Nayantara Sheoran Appleton published a blog post confronting academia's metaphorical use of "decolonize." She suggests several $D$ words that, as she explains, "talk about the work we are doing now, while thinking of a decolonized sovereign nation future" (2019). More appropriate claims are that my seminar diversifies the syllabus and curriculum by focusing almost exclusively on Indigenous authors and artists, and thus decentres Euro-American knowledge systems. The course digresses from the canon by studying Indigenous musicians working within Euro-American classical genres and by studying non-classical genres (a process that devalues the hierarchy that positions Euro-American classical music as superior).

Decolonizing pedagogies requires that students recognize structures of settler colonialism as ongoing and that Indigenous ways of knowing, doing, and being are centred. Because I am not Indigenous, Indigenous-made films and creative work and Indigenous scholars' writing were some ways students learned directly from Indigenous individuals. The video chat with Tate was also a special opportunity for the class. As I continue to build relationships with COTRAIC, the EC2SS, and other local Indigenous artists, activists, and scholars, this seminar will become increasingly collaborative. Reflecting on la paperson's words, I have hope that I contribute to decolonial work within the university. Tuck and Yang argue that critical pedagogy (sometimes labelled "decolonizing pedagogies") is not actually decolonization: settler colonialism persists, despite settlers' deeper awareness. Nonetheless, what happens in my 
music classroom is meaningful, difficult work because it exposes the technologies of settler colonialism and calls me and my students to reject the exploitative values of settler colonialism (Tuck and Yang 2012, 21). Thus, I would label this seminar an anti-colonial course. Ultimately, the work matters more than the label. However, labels guide the scope of my work as a university musicology professor. My course and research would be more realistically called the kind of "intermediate steps towards decolonization" $(2019,127)$ that Robin Attas describes in her own popular music teaching.

One semester is relatively brief when compared to the years that we have been indoctrinated into settler colonial myths and placated by the power and privilege it grants many of us. It is a mess to untangle, and it is easy for settlers to slip into moves to innocence. Yet this seminar is a scrap of the colonial university that can assemble decolonizing machines. Yang has made it clear that operating on the university's technologies (among which I include myself) as part of the plurality of the scyborg ${ }^{14}$ to form a decolonizing university is not "easy and obvious" (la paperson 2017, 24). He explains, "Listen: you will need to remember this when you are accused of destruction. Attach a pacemaker to the heart of those machines you hate; make it pump for your decolonizing enterprise; let it tick its own countdown. Ask how, and how otherwise, of the colonizing machines. Even when they are dangerous" (24). Overwhelmed but determined, I embrace an unknown and difficult future as a complicit settler musicologist with decolonial desires.

\section{REFERENCES}

Adams, Nicole, Todd D. Little, and Richard M. Ryan. 2017. "Self-Determination Theory." In Development of Self-Determination through the Life-Course, edited by Michael L. Wehmeyer, Karrie A. Shogren, Todd D. Little, and Shane J. Lopez, 47-54. Dordrecht, the Netherlands: Springer.

Amico, Stephen. 2020. "'We Are All Musicologists Now'; or, the End of Ethnomusicology." Journal of Musicology 37 (1): 1-32.

Appleton, Nayantara Sheoran. 2019. "Do Not 'Decolonize' ... If You Are Not Decolonizing: Progressive Language and Planning beyond a Hollow Academic Rebranding." Critical Ethnic Studies Blog, 4 February. http://www. criticalethnicstudiesjournal.org/blog/2019/1/21/do-not-decolonize-if-youare-not-decolonizing-alternate-language-to-navigate-desires-for-progressive-academia-6yssg.

Arnaquq-Baril, Alethea. 2016. Angry Inuk. Film Movement.

Attas, Robin. 2019. "Strategies for Settler Decolonization: Decolonial Pedagogies in a Popular Music Analysis Course." Canadian Journal of Higher Education / Revue Canadienne d'enseingement supérieur 49 (1): 125-39.

Avery, Dawn Ieriho:Kwats. 2012. "Tékeni-Two Worlds, Many Borders: A Look at Classical Native Music through Indigenous Eyes." MUSICultures 39 (1): 129-68. https://journals.lib.unb.ca/index.php/MC/article/view/19998.

14 Yang's term adds an 's' to cyborg "to name the structural agency of persons who have picked up colonial technologies and reassembled them to decolonizing purposes" (la paperson 2017, xiv). 
Bonds, Anne, and Joshua Inwood. 2016. "Beyond White Privilege: Geographies of White Supremacy and Settler Colonialism." Progress in Human Geography 40 (6): 715-33.

Browner, Tara. 2009. Music of the First Nations: Tradition and Innovation in Native North America. Urbana: University of Chicago Press.

Downie, Gord, and Jeff Lemire. 2016. Secret Path. Toronto: Arts \& Crafts Productions.

Garneau, David. 2012. "Imaginary Spaces of Conciliation and Reconciliation." West Coast Line: Reconcile This! 74:28-38.

- 2016. "Imaginary Spaces of Conciliation and Reconciliation: Art, Curation and Healing." In Arts of Engagement: Taking Aesthetic Action in and beyond the Truth and Reconciliation Commission of Canada, edited by Dylan Robinson and Keavy Martin, 21-42. Waterloo, ON: Wilfrid Laurier University Press.

Hatzis, Christos. 2014. Going Home Star: Truth and Reconciliation. Chor. Mark Godden. Dir. André Lewis. Royal Winnipeg Ballet.

Hoefnagals, Anna, and Beverley Diamond, eds. 2012. Aboriginal Music in Contemporary Canada: Echoes and Exchanges. Montreal and Kingston: McGill-Queen's University Press.

Kajikawa, Loren. 2019. "The Possessive Instrument in Classical Music: Confronting Legacies of White Supremacy in U.S. Schools and Departments of Music." In Seeing Race Again: Countering Colorblindness across the Disciplines, edited by Kimberlé Williams Crenshaw, Luke Charles Harris, Daniel Martinez HoSang, and George Lipsitz, 155-74. Oakland, CA: University of California Press.

Keene, Adrienne. 2019. "Advice for Non-Indigenous Instructors of Native Studies." Indian Country Today, 1 February. https://newsmaven.io/indiancountrytoday/opinion/advice-for-non-indigenous-instructors-of-native-studies-fclZSBHr5kmVtuwSx5KNhA/.

King, Thomas. 2012. The Inconvenient Indian: A Curious Account of Native People in North America. Minneapolis: University of Minnesota Press.

Knyt, Erinne E. 2013. "Rethinking the Music History Research Paper Assignment." Journal of Music History Pedagogy 4 (1): 23-37.

la paperson (K. Wayne Yang). 2017. A Third University Is Possible. Minneapolis: University of Minnesota Press.

Levine, Victoria Lindsay, and Dylan Robinson. 2019. Music and Modernity among First Peoples of North America. Middletown, CT: Wesleyan University Press.

Maracle, Lee. 1993. Ravensong. Vancouver: Press Gang.

Meyer, Anne, David H. Rose, and David Gordon. 2014. Universal Design for Learning: Theory and Practice. Wakefield, MA: CAST Professional Publishing.

Minderhout, David J., and Andrea T. Frantz. 2008. Invisible Indians: Native Americans in Pennsylvania. Amherst, NY: Cambria.

Moreton-Robinson, Aileen. 2015. The White Possessive: Property, Power, and Indigenous Sovereignty. Minneapolis: University of Minnesota Press. 
Peters, Evelyn J., and Chris Andersen. 2013. Indigenous in the City: Contemporary Identities and Cultural Innovation. Vancouver: UBC Press.

Regan, Paulette. 2010. Unsettling the Settler Within: Indian Residential Schools, Truth Telling, and Reconciliation in Canada. Vancouver: UBC Press.

Smith, Andrea. 2012. "Indigeneity, Settler Colonialism, White Supremacy." In Racial Formation in the Twenty-First Century, edited by Daniel Martinez HoSang, Oneka LaBennett, and Laura Pulidao, 66-9o. Berkeley: University of California Press.

Stout, Mary. 2012. Native American Boarding Schools. Santa Barbara, CA: Greenwood.

Strachan, Jeremy, and Patrick Nickleson. 2018. "Doing Long Work: Critical Perspectives on Indigenous-Settler Collaboration in Canadian Art Music." University of Toronto Quarterly 87 (4): 83-101.

Tagaq, Tanya. 2014. Animism. CD. Six Shooter Records.

Truth and Reconciliation Commission of Canada. 2015. "Honouring the Truth, Reconciling for the Future: Summary of the Final Report of the Truth and Reconciliation Commission of Canada." http://nctr.ca/reports.php.

Tuck, Eve, and K. Wayne Yang. 2012. "Decolonization Is Not a Metaphor." Decolonization: Indigeneity, Education \& Society 1 (1): 1-40.

Vowel, Chelsea. 2016. Indigenous Writes: A Guide to First Nations, Métis \& Inuit Issues in Canada. Winnipeg: Highwater.

Woloshyn, Alexa. 2012. "The Recorded Voice and the Mediated Body in Contemporary Canadian Electroacoustic Music." PhD diss., University of Toronto.

. 2015. "Hearing Urban Indigeneity in Canada: Self-Determination, Community Formation, and Kinaesthetic Listening with A Tribe Called Red." American Indian Culture and Research Journal 39 (3): 1-23. .2016. "A Tribe Called Red's Halluci Nation: Sonifying Embodied Global Allegiances, Decolonization, and Indigenous Activism.” Intersections: Canadian Journal of Music 36 (2): 101-9.

. 2017. "Welcome to the Tundra: Tanya Tagaq's Creative and Communicative Agency as Political Strategy." Journal of Popular Music Studies 29 (4). https://doi.org/10.1111/jpms.12254.

_ 2019. "Sounding the Halluci Nation: Decolonizing Race, Masculinity, and Global Solidarities with A Tribe Called Red." In Popular Music and the Politics of Hope: Queer and Feminist Interventions, edited by Susan Fast and Craig Jennex, 151-71. Abingdon, UK: Routledge.

- 2020. "Reclaiming the 'Contemporary' in Indigeneity: The Musical Practices of Cris Derksen and Jeremy Dutcher." In "Contemporary Music and Its Futures," special issue, Contemporary Music Review 39 (2): 206230. https://doi.org/10.1080/07494467.2020.1806627.

Younging, Gregory. 2018. Elements of Indigenous Style: A Guide for Writing by and about Indigenous Peoples. Edmonton, AB: Brush Education. 


\section{ABSTRACT}

For those of us with decolonial desires, the university classroom is a potential space of disruption and reorganization. Our courses, course materials, teaching tools, students, and our own bodies and minds are all technologies that can subvert the colonial machine (la paperson 2017). In the first section, I contextualize my decolonial desires as a non-U.S.-citizen settler Canadian musicologist in the United States. The work of David Garneau, Aileen Moreton-Robinson, Andrea Smith, Eve Tuck, and K. Wayne Yang illuminates my positionality and power. In the second section, I provide an example of one way I'm disrupting the typical curricula and classroom experiences in a Euro-American classical music school. I discuss my course entitled "North American Indigenous Music Seminar" (NAIMS), including the course structure and content, and decolonizing strategies. Student responses to interviews about the course are interspersed with the discussion of my seminar plans and challenges to claims of "decolonization." Their responses reveal some successes and many limits for anti-colonial and decolonial work in a single-semester course.

\section{RÉSUMÉ}

Pour ceux d'entre nous qui ont des désirs décoloniaux, la salle de classe universitaire est un espace potentiel de rupture et de réorganisation. Nos cours, notre matière, nos outils pédagogiques, nos étudiant-e-s et nos propres corps et esprits sont autant de technologies qui peuvent renverser la machine coloniale (la paperson 2017). Dans la première section, je contextualise mes désirs décoloniaux en tant que musicologue canadienne, non-citoyenne américaine aux États-Unis. Les travaux de David Garneau, Aileen Moreton-Robinson, Andrea Smith, Eve Tuck et K. Wayne Yang soulignent mon positionnement et mon pouvoir. Dans la deuxième section, je donne en exemple une façon dont je perturbe les programmes et les expériences universitaires typiques dans une école de musique classique euroaméricaine. Je discute de mon cours intitulé "North American Indigenous Music Seminar» (NAIMS), notamment la structure et le contenu du cours, ainsi que les stratégies de décolonisation. Les réponses des étudiante-s aux entretiens sur le cours sont entrecoupées de la discussion de mes plans de séminaire et des défis relatifs à la «décolonisation». Leurs réponses révèlent quelques succès et de nombreuses limites au travail anticolonial et décolonial dans un cours d'un semestre.

\section{BIOGRAPHY}

Alexa Woloshyn is assistant professor of musicology at Carnegie Mellon University. Current research projects examine Indigenous musicians' use of mediating technologies to construct and interrogate notions of "modern" Indigeneity, including Tanya Tagaq, A Tribe Called Red, Cris Derksen, and Melody McKiver. Her work has been published in the Journal of Popular Music Studies, the American Indian Culture and Research Journal, and Intersections. 